\title{
Study of the Socioeconomic Status of Women Vermicompost-Producing Farmers in Kashmir Valley
}

\author{
H. Hamadani*, J. D. Parrah, N. Hassan, R. A. Dar, F. D. Sheikh, \\ R. M. Shah, P. A. Reshi and S. A. Haq
}

Mountain Livestock Research Institute, Sher-e-Kashmir University of Agricultural Sciences and Technology of Kashmir, Manasbal, Ganderbal - 193504 (J\&K), India

*Corresponding author

\begin{abstract}
A B S T R A C T
Vermicomposting venture has a potential to help farmers fetch reasonable profits with little inputs. Vermicomposting is gaining popularity among rural women folk and is empowering them in many ways. The same has gained popularity among the women folks too. A study was planned to assess the socioeconomic status of women farmers getting their livelihood from vermicompost production in the districts of Bandipora and Baramulla of Jammu and Kashmir. The result revealed that $68.2 \%$ farmers lived in nuclear families, while the remaining $31.8 \%$ lived jointly, with the average nuclear and joint family size of $5.6 \pm 0.43$ and $10.71 \pm$ 1.65 members respectively. Majority of the families were headed by males (86.4 $\%$ ) with the overall head's literacy rate being $18.2 \%$. Literacy rate of the women vermicompost farmers average to $27.3 \%$. Overall literacy rate of male members in their families was found to be more than the female members. The family constituted of $51.14 \%$ earning male members and $47.04 \%$ earning female members. Livestock owned by them included cattle, sheep, goat, horses, ducks and geese. Overall, $81.8 \%$ famers owned land which they used for varied purposes.
\end{abstract}

\section{Keywords}

Empowerment, Education,

Livelihood,

Vermicompost, Women

Article Info

Accepted:

12 March 2020

Available Online:

10 April 2020

\section{Introduction}

Vermicompost farming have been identified as one of the feasible agri-business activities for the rural women (Kusum, 2005; Baraskar et al., 2018a), requiring less time and investment (Baraskar et al., 2018a). The production technique is simple and unlike crop production is not affected much by the climatic changes (Baraskar et al., 2018a). Various studies have indicated vermicompost farming as an additional source of income (Meti, 2013; Baraskar et al., 2018ab) and thereby empowering rural women to a reasonable extent. Diiro et al., (2018) stated that women empowerment contributes not 
only in reducing the gender gap in agriculture, but also in improved productivity from farms managed by women.

The scope of vermicompost production business is growing with the increase in the demand for vermicompost owing to the popularization of organic agriculture. Increased awareness among the masses regarding the ill-effects of pesticides and fertillizers are forcing health conscious consumers to prefer organic foods. Vermicomposting has gained popularity in the Valley of Kashmir as well. Rural women in the districts of Bandipora and Baramulla have organized themselves into self-help groups with the help local NGOs working in the area and started their small scale ventures of vermicompost production for earning their livelihood. Keeping this in view, a study was planned to understand the socio-ecomic status of women farmers engaged in vermicompost production.

\section{Materials and Methods}

The study was conducted in two districts of Jammu and Kashmir viz. Bandipora (Zone 1) and Baramulla (Zone 2), which are spread over an area of 3200 (Anonymous 2020a) and 4190 (Anonymous, 2020b) $\mathrm{km}^{2}$, with a population density of 1117 (Anonymous, 2020a) and 305 (Anonymous, 2020b) inhabitants per square kilometer, respectively. More than 200 women in these two districts, organized into self-help groups produce vermicompost to earn their livelihood.

The present study targeted 20 such self-help groups, comprising of 220 women. Out these, $10 \%$ women were interviewed using a pretested questionnaire and information regarding their family structure, type, size and composition, literacy level, livelihood status, occupation, land holding status and livestock inventory was obtained. The data was tabulated, classified and analyzed by drawing averages and percentages where ever required. The means between the groups were compared by using Student's t-test (Snedecor and Cochran, 1980). The percentage data was subjected to arcsine or square root transformation as required before subjecting it to the test for significance.

\section{Results and Discussion}

\section{Family structure}

The family structure of women vermicompost farmers is given in Table 1. Most of the families were found to be nuclear as has also been observed by Kusum (2005) and Ankita (2012) in their respective studies. Majority of the families were headed by male members in both the districts. Average family size in the zone 1 was higher than the zone 2 . The study of family composition revealed that the proportion of male members was slightly more than that of female members.

\section{Education status}

Majority of the family heads were illiterate. A low proportion of women farmers were educated but their education-level was below matric only. Majority of them were illiterate, which is in agreement to the reports of Kusum (2005), Meti (2013) and Ankita (2012). Literacy rate of the male members was found to be more than their female counterparts. Table 2 gives the details about the education status of their families. A positive trend in the education status in the present study was observed across the generations as depicted in Figure 1. Baraskar et al., (2018b) indicated a positive influence of education on the employment generation through vermicomposting. Umale et al., (2014) also suggested that women farmers with higher education have higher level of role performance in vermiculture enterprise. 
Table.1 Family structure of women vermicompost farmers

\begin{tabular}{|c|c|c|c|}
\hline \multirow[t]{2}{*}{ Parameter } & \multicolumn{3}{|c|}{ Percentage of farmers } \\
\hline & Zone 1 & Zone 2 & Overall \\
\hline \multicolumn{4}{|l|}{ 1. Family Type (\%) } \\
\hline i. Nuclear & $73.3^{b}$ & 57.1 & $68.2^{\mathrm{b}}$ \\
\hline ii. Joint & $26.7^{\mathrm{a}}$ & 42.9 & $31.8^{\mathrm{a}}$ \\
\hline \multicolumn{4}{|l|}{ 2. Family Head (\%) } \\
\hline i. Male headed & $80^{b}$ & $100^{b}$ & $86.4^{b}$ \\
\hline ii. Female headed & $20^{\mathrm{aA}}$ & $0^{\mathrm{aB}}$ & $13.6^{\mathrm{a}}$ \\
\hline \multicolumn{4}{|l|}{ 3. Average family size } \\
\hline i. Nuclear family & $5.72 \pm 0.55^{\mathrm{a}}$ & $5.52 \pm 0.62^{\mathrm{a}}$ & $5.6 \pm 0.43^{\mathrm{a}}$ \\
\hline ii. Joint family & $12.5 \pm 2.53^{b}$ & $8.33 \pm 1.20^{b}$ & $10.71 \pm 1.65^{b}$ \\
\hline iii. Overall & $7.53 \pm 1.08$ & $6.57 \pm 0.84$ & $7.23 \pm 0.78$ \\
\hline \multicolumn{4}{|c|}{ 4. Family composition $(\%)$} \\
\hline i. Adult males & $2.46 \pm 0.44$ & $2.14 \pm 0.40$ & $2.35 \pm 0.32$ \\
\hline ii. Adult females & $2.14 \pm 0.311$ & $2.28 \pm 0.35$ & $2.19 \pm 0.24$ \\
\hline iii. Male children & $1.63 \pm 0.24$ & $1.5 \pm 0.22$ & $1.59 \pm 0.17$ \\
\hline iv. Female children & $1.30 \pm 0.15$ & $1.50 \pm 0.5$ & $1.36 \pm 0.17$ \\
\hline
\end{tabular}

Table.2 Education status of women vermicompost farmers

\begin{tabular}{|c|c|c|c|}
\hline \multirow{2}{*}{ Parameter } & \multicolumn{3}{|c|}{ Percentage of farmers } \\
\hline & Zone 1 & Zone 2 & Overall \\
\hline \multicolumn{4}{|l|}{ 1. Head's literacy (\%) } \\
\hline i. Literate & $20.0^{\mathrm{a}}$ & $14.3^{\mathrm{a}}$ & $18.2^{\mathrm{a}}$ \\
\hline ii. Illiterate & $80.0^{\mathrm{a}}$ & $85.7^{\mathrm{b}}$ & $81.8^{\mathrm{b}}$ \\
\hline \multicolumn{4}{|c|}{ 2. Women farmer's education level (\%) } \\
\hline i. Below matric & $26.7^{\mathrm{a}}$ & 28.6 & $27.3^{\mathrm{a}}$ \\
\hline ii. Nil & $73.3^{\mathrm{b}}$ & 71.4 & $72.7^{\mathrm{b}}$ \\
\hline \multicolumn{4}{|c|}{ 3. Children sent to school (\%) } \\
\hline i. All & 93.3 & 85.7 & 90.9 \\
\hline ii. None & 0.0 & 0.0 & 0.0 \\
\hline iii. Only some & 6.7 & 14.3 & 9.1 \\
\hline \multicolumn{4}{|c|}{ 4. Literacy rate of family members (\%) } \\
\hline i. Male members & $69.06 \pm 4.74$ & $75.00 \pm 9.44$ & $71.14 \pm 4.42$ \\
\hline ii. Female members & $51.07 \pm 22.433$ & $47.61 \pm 15.61$ & $49.92 \pm 6.33$ \\
\hline iii. Overall & $58.13 \pm 4.74$ & $61.20 \pm 9.33$ & $59.16 \pm 4.31$ \\
\hline
\end{tabular}

${ }^{a b}$ Values with different superscripts in columns differ significantly $(\mathrm{P}<0.05)$ 
Table.3 Livelihood status of women vermicompost farmers

\begin{tabular}{|c|c|c|c|}
\hline Parameter & Zone 1 & Zone 2 & Overall \\
\hline \multicolumn{4}{|c|}{ 1. Proportion of Earning members (\%) } \\
\hline i. Male members & $54.32 \pm 7.11$ & $45.23 \pm 9.93$ & $51.14 \pm 5.72$ \\
\hline ii. Female members & $47.26 \pm 5.87$ & $46.59 \pm 4.37$ & $47.04 \pm 4.11$ \\
\hline iii. Overall & $48.11 \pm 4.61$ & $44.37 \pm 3.23$ & $46.87 \pm 3.23$ \\
\hline \multicolumn{4}{|c|}{ 2. Primary Occupation of Family Head } \\
\hline i. Labour & $46.7^{\mathrm{b}}$ & $57.0^{\mathrm{b}}$ & $50.0^{\mathrm{b}}$ \\
\hline ii. Artisan & $40.0^{\mathrm{b}}$ & $14.3^{\mathrm{a}}$ & $31.8^{\mathrm{a}}$ \\
\hline iii. Vermicompost & $13.3^{\mathrm{ab}}$ & $0.0^{\mathrm{a}}$ & $9.1^{\mathrm{a}}$ \\
\hline iv. Nil & $0.0^{\mathrm{aA}}$ & $2.0^{\mathrm{aB}}$ & $9.1^{\mathrm{a}}$ \\
\hline \multicolumn{4}{|l|}{ 3. Land Holding Status } \\
\hline i. Land holding (\%) & $86.7^{\mathrm{a}}$ & 71.4 & $81.8^{\mathrm{b}}$ \\
\hline ii. Landless (\%) & $13.3^{\mathrm{a}}$ & 28.6 & $18.2^{\mathrm{a}}$ \\
\hline \multicolumn{4}{|l|}{ 4. Land Holding Size } \\
\hline $\begin{array}{l}\text { Land Holding Size } \\
\text { (Kanals) }\end{array}$ & $9.65 \pm 3.61$ & $5.00 \pm 1.26$ & $18.00 \pm 2.65$ \\
\hline \multicolumn{4}{|c|}{ 5. Livestock Strength (average no. of heads) } \\
\hline i. Cattle & $1.23 \pm 0.16$ & $1.00 \pm 0.00$ & $1.2 \pm 0.14$ \\
\hline ii. Sheep & $4.00 \pm 1.52$ & $0.00 \pm 0.00$ & $3.00 \pm 1.53$ \\
\hline iii. Goat & $2.20 \pm 0.80$ & $1.40 \pm 0.24$ & $1.80 \pm 0.42$ \\
\hline iv. Horses & $1.00 \pm 0.00$ & $1.00 \pm 0.00$ & $1.00 \pm 0.00$ \\
\hline v. Poultry (Chicken) & $12.58 \pm 4.47$ & $20.58 \pm 9.20$ & $12.82 \pm 3.99$ \\
\hline vi. Duck/geese & $5.00 \pm 0.00$ & $16.5 \pm 13.50$ & $9.60 \pm 5.11$ \\
\hline
\end{tabular}

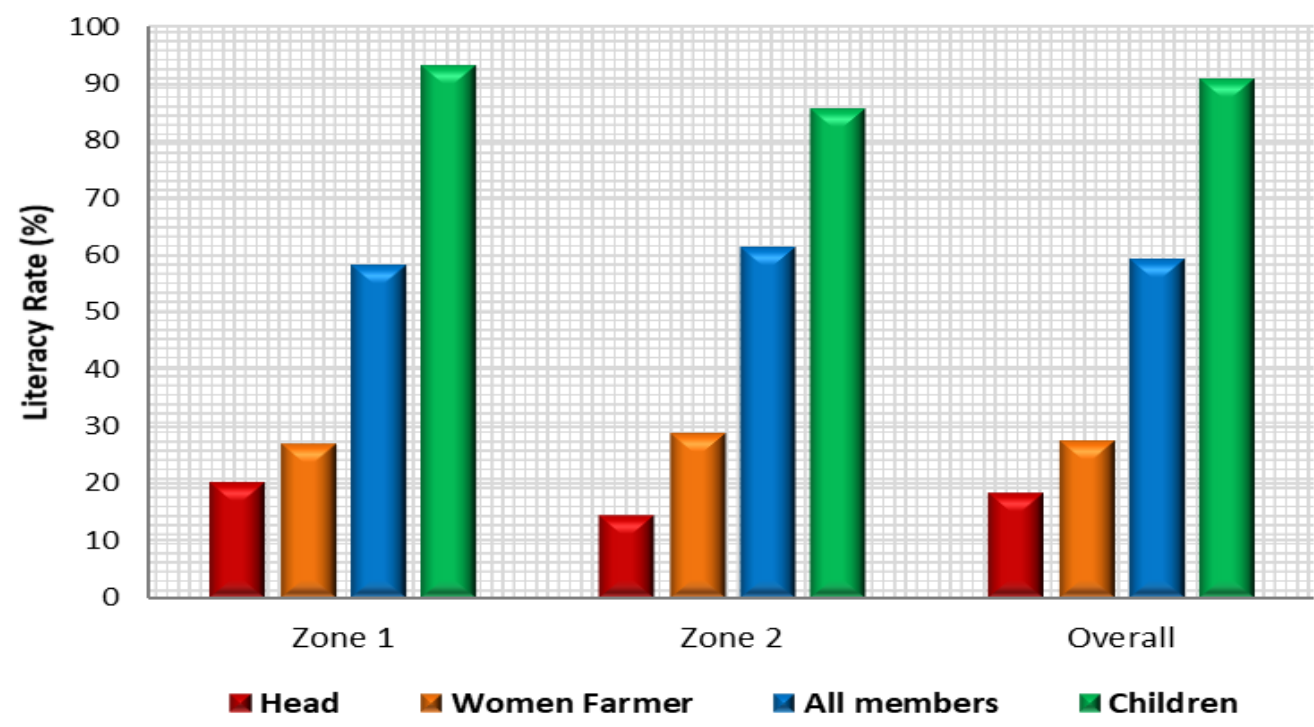

Figure.1 A graphical representation of literacy rate across generations indicating a positive trend 


\section{Livelihood status}

The overview of livelihood status of women farmers associated with vermicomposting is given in Table 3. Percentage of female members contributing to the family income, was almost equal to the percentage of the male earning members. This gives an indication of women empowerment in the rural areas, where women mainly engaged in vermicompost production, also contributed some share to the income of their respective families, as has also been concluded by Meti (2013) and Baraskar et al., (2018b). The overall scenario of family heads was that $50 \%$ of them were engaged in labour work, while as $9.1 \%$ were not working at all. More number of farmers owned land in zone 1 compared to zone 2 . The livestock owned by them included cattle, sheep, goat, horses, chicken, ducks and geese.

The study revealed that vermicompost production empowered rural women socioeconomically as was indicated by their contribution to the family income as well as by the capacity of being able to send their children to schools.

\section{Acknowledgements}

The authors acknowledge the support of SKUAST-Kashmir and IGSSS, Kashmir for the conduct of this study.

\section{References}

Anonymous, 2020a. District Baramulla, Government of Jammu and Kashmir. https://baramulla.nic.in/

Anonymous, 2020b. District Bandipore, Government of Jammu and Kashmir. https://bandipore.nic.in/

Ankita, T. 2012. Feasibility of vermicomposting as an enterprise for rural women. M.Sc Thesis, Chaudhary
Charan Singh Haryana Agricultural University, Hisar, India

Baraskar, M., Choudhary, S., Wankhede, A., Jain, S.K. and Verma, D.K. 2018a. Impact of Socio Personal Attributes of Vermicompost Production in Terms of Income and Employment Generation in Hoshangabad District (Madhya Pradesh). SSRG International Journal of Agriculture \& Environmental Science 5(4): 34-36.

Baraskar, M. M., Choudhary, S., Wankhede, A. and Jain, S.K. 2018b. Impact of Vermicompost Production in Terms of Income and Employment Generation. Global Journal of Applied Agricultural Research. 8(2): 111-116.

Diiro, G. M., Seymour, G., Kassie, M., Muricho, G. and Muriithi, B. W. 2018. Women's empowerment in agriculture and agricultural productivity: Evidence from rural maize farmer households in western Kenya. PLoS One. 13(5): 0197995. doi:10.1371/journal.pone.0197995

Kusum 2005. Capacity-building of farm women through agri-business activities. M.Sc Thesis, Chaudhary Charan Singh Haryana Agricultural University, Hisar, India

Meti, S. K. 2013. Social and economic empowerment of farm women in agro based entrepreneurship for sustainable income. In: Proceeding of the International Conference on Social Science Research, ICSSR 2013. June 2013, Penang, Malaysia.

Snedecor, G.W. and Cochran, W.G. 1980. Statisical Methods, 7th Edition. Iowa State University Press Ames, Iowa.

Umale, P. B., Chinchmalatpure, U. R. andBharane, S. B. 2014. Role performance of rural women in vermiculture enterprise. Journal of Rural Development. 33(1): 101-110. 


\section{How to cite this article:}

Hamadani, H., J. D. Parrah, N. Hassan, R. A. Dar, F. D. Sheikh, R. M. Shah, P. A. Reshi and Haq, S. A. 2020. Study of the Socioeconomic Status of Women Vermicompost-Producing Farmers in Kashmir Valley. Int.J.Curr.Microbiol.App.Sci. 9(04): 1486-1491. doi: https://doi.org/10.20546/ijcmas.2020.904.175 